\title{
Efficiency Comparison between Conventional and Modern Port Operation System for Small-Scale Dry Bulk Cargo
}

\author{
Aulia Tiara ${ }^{1, *}$ and Julfikhsan Ahmad Mukhti $^{2}$ \\ ${ }^{1,2}$ Institut Teknologi Bandung, Jalan Ganesha No. 10 Bandung, Indonesia
}

\begin{abstract}
Since the launching of Sea Toll Road Program in 2015, the improvement in ports' operation systems has become Indonesia's foremost necessity. This improvement commonly leads to equipment modernization, while realistically, modern equipment does not always amount to a productive performance, especially in the context of small-scale ports. Instead, it is prone to creating wasteful capital and maintenance cost as well as making the planning time ineffective. This study compares two options of port operation systems in a small port, which is conventional and technologically-advanced method for dry bulk cargo. It results in thin gaps between each option's financial assessment variables, which are Internal Rate of Return, Benefit/Cost Ratio and Payback Period, regardless of a stark difference between each option's equipment cost. This study concludes that with the right approach, the conventional operation system is still the most efficient option compared to its contemporary opposite.
\end{abstract}

\section{Introduction}

In 2015, Indonesia started a program to set the route to connect existing main ports throughout the nation through a fixed shipping schedules. The program, known as "Tol Laut" (Sea Toll Route) aims to improve the efficiency of logistics and distribution by directing smaller ports, which consists of collector and feeder ports, to ship the cargo from or to the main ports connected in the Sea Toll Route.

The Sea Toll Route is predicted to increase the overall logistics distribution throughout the nation as it may stimulate the current economic development in Eastern Indonesia which is relatively low compared to the market in the Middle and Western Indonesia [1]. Part of the Sea Toll Route plan is to improve the infrastructure and technology on the existing national ports. As an example, PT Pelabuhan Indonesia III launched Teluk Lamong Terminal in 2016, which is a container and dry bulk terminal with modern unloading equipment such as Grab Ship Unloader and Ship-To-Ship Crane.

The technological improvement that is undergoing on larger scale ports owned by national port operators (PT Pelabuhan Indonesia I to IV), however, should not be adapted for smaller-scale ports without careful planning. The improvement method is critically suitable for some ports to achieve a beneficial return, especially for smaller ports in Indonesia in which facility, human resource, and logistics throughput disparity between port scales are relatively large.

One example of reverted approach is in the Sunda Kelapa Port, which is a collector port owned by PT Pelabuhan Indonesia II. A multi-purpose terminal with harbor mobile cranes was planned to be built in the Post
VI of Sunda Kelapa in 2016. However, the plan eventually canceled due to the low projection of incoming sand bulk cargo, which was set as the main handled goods in the planned terminal, and a new plan to make the Sunda Kelapa Port as a heritage port in the future with completely different infrastructures. Should the planning approach started from the most basic improvement in form of deck-on-pile terminal with excavator and truck for unloading operation, the terminal may be built before the new plan is settled and generate valuable income for the upcoming port improvements.

As to Sunda Kelapa Post VI Jetty, this approach will have the same possibility to be applied in other smaller ports. However, the approach is not only risky for small infrastructures with barriers in operational use but also burdening regarding budget and planning time due to added maintenance and preparation scheme planning. As a nation with a high number of population, a simpler method that utilizes Indonesia's human resource should be prioritized over advanced, complicated technology.

In this study, two approaches are compared for port operation improvement based on these philosophies: human resource utilization and advanced technology. Sunda Kelapa Post VI Terminal development is chosen as the sample case. The first approach uses Excavator for cargo unloading, representing the human resource utilization approach and will be referred as "Conventional System" in this study. The second approach uses Vertical Screw Conveyor for cargo unloading, representing the advanced technology approach and will be referred as "Modern System" in this study. The terminal berth structure for both approaches, however, is designed to serve Harbour Mobile Crane, which is heavier than

* Corresponding author: auliauliatiara@gmail.com 
Excavator and Vertical Screw Conveyor mentioned before. Finally, a financial analysis is conducted to compare the efficiency and effectiveness for each approach which uses parameters such as Benefit/Cost Ratio (BCR), Internal Rate of Return (IRR) and Payback Period (PP).

\section{Operational System for Dry Bulks}

The study is based on a survey, investigation, and design (SID) project of Post VI Jetty in Indonesia Port Company (IPC) branch in Sunda Kelapa, Jakarta [1]. Jakarta. It has an elevation of $+3.5 \mathrm{~m}$ from the low water surface (LWS), a length of $100 \mathrm{~m}$ and is expected to receive a single barge of 5,000 ton of sand bulk cargo.

Due to the change of level of the barge towards the jetty in the unloading process, the operational scheme in all the options is divided into two separated phases. The elevation change is shown in Fig 1. The first phase, named Phase One, is the unloading of the barge's cargo from full to $1 / 3$ part unloaded. After the $1 / 3$ part of the cargo is unloaded, the barge reaches the same level as the jetty. The second phase, named Phase Two, is the unloading of the barge's cargo from 1/3 part unloaded to fully unloaded. In a fully-unloaded cargo condition, the barge is on a higher level than the jetty, which requires all unloading methods presented in this study to adjust midoperation.

\subsection{Conventional System (Excavator - Dump Truck}

Taking an operational reference on PT Pelabuhan Indonesia II's Muarajati Coal Wharf in Cirebon, this study simulates an operational scheme for sand bulk using two units of Excavators as unloading equipment and Dump Truck as transfer equipment as shown in Fig 2. This operating system is widely used in unloading dry bulks in Indonesian ports, thus making it a 'conventional' type of system in this study.

In Phase One condition, 2 Excavators unload the barge's cargo into 2 Dump Trucks per activity. However, Excavator has a limited arm reach, so to fully unload the barge into the end of Phase Two condition, the Excavators and Dump Trucks need to get inside the barge. Therefore, in between Phase One and Phase Two condition, a preparation for loading the equipment to the inside of the barge is conducted. This preparation includes the opening of the cargo hold, the moving and locking of ramp door, maneuvering of Excavators and preparation time to make ways for Dump Trucks to move into the barge. This whole preparation process is named the Intermediate Phase.

After the Intermediate Phase is done, Phase Two condition can be conducted. In this phase, each of the Dump Trucks enters the barge via one-way ramp door. In the barge, those 2 Excavators perform the unloading process in parallel until all the sand bulk cargo is unloaded into Dump Trucks.
For this condition, the study refers to the survey conducted by PT LAPI ITB on Excavator's duration to fill a 25 Ton Dump Truck [2].

\subsection{Modern System (Vertical Screw Conveyor - Conveyor Belt)}

Taking an operational reference on Talin Power Plant in Taipei, Taiwan, this option studies operational scheme of a Vertical Screw Conveyor ship unloader which moves the sand bulk cargo into a Conveyor Belt system as shown in Fig 3. The Screw Conveyor Belt then transfers the sand bulk cargo to a dedicated cargo bulk terminal.

In Phase One condition, the Screw Conveyor unloads the $1 / 3$ part of the barge's cargo to a Conveyor Belt system. The Conveyor Belt system of the equipment then transfers the cargo to the terminal.

After the 1/3 part of the cargo is loaded, the Vertical Screw Conveyor needs another equipment to push the cargo into the Screw Conveyor's suction direction. For that reason, a single Bulldozer needs to be loaded into the barge. The condition marks the beginning part of the Intermediate Phase condition. During this condition, a preparation for Bulldozer loading into the barge is conducted, which includes the opening of the cargo hold, the moving and locking of ramp door, and lastly, the maneuvering of Bulldozer into the inside of the barge. After Intermediate Phase is finished, the process will be proceeded with the Phase Two condition, in which the unloading of cargo is continued with the help of Bulldozer.

\section{Productivity Measurement}

PT Pelabuhan Indonesia II [3] provides an approach for berth time measurement as shown in Fig 4, which consists of Berth Working Time and Not Operating Time. Berth Working Time consists of actual operational time, stated as Effective Time and Idle Time. Using the approach as reference, this study divides each Effective Time of the two systems into three comparative phases, which are Phase One, Intermediate Phase and Phase Two.

Based on Fig 4, Effective Time (ET) follows Equation (1) below.

$E T=$ Phase One + Intermediate Step + Phase Two

In this study, Idle Time (IT) is assumed to follow Equation (2), while Berth Working Time (BWT) automatically follows Equation (3).

$$
\begin{gathered}
I T=20 \% X(E T) \\
B W T=E T+I
\end{gathered}
$$

For both systems, Not Operating Time (NOT) is assumed to occur once for every work shift. One work shift is 8 hours long, and Not Operating Time is assumed to be one-hour long. That way, this variable follows Equation (4).

\footnotetext{
* Corresponding author: auliauliatiara@gmail.com
} 


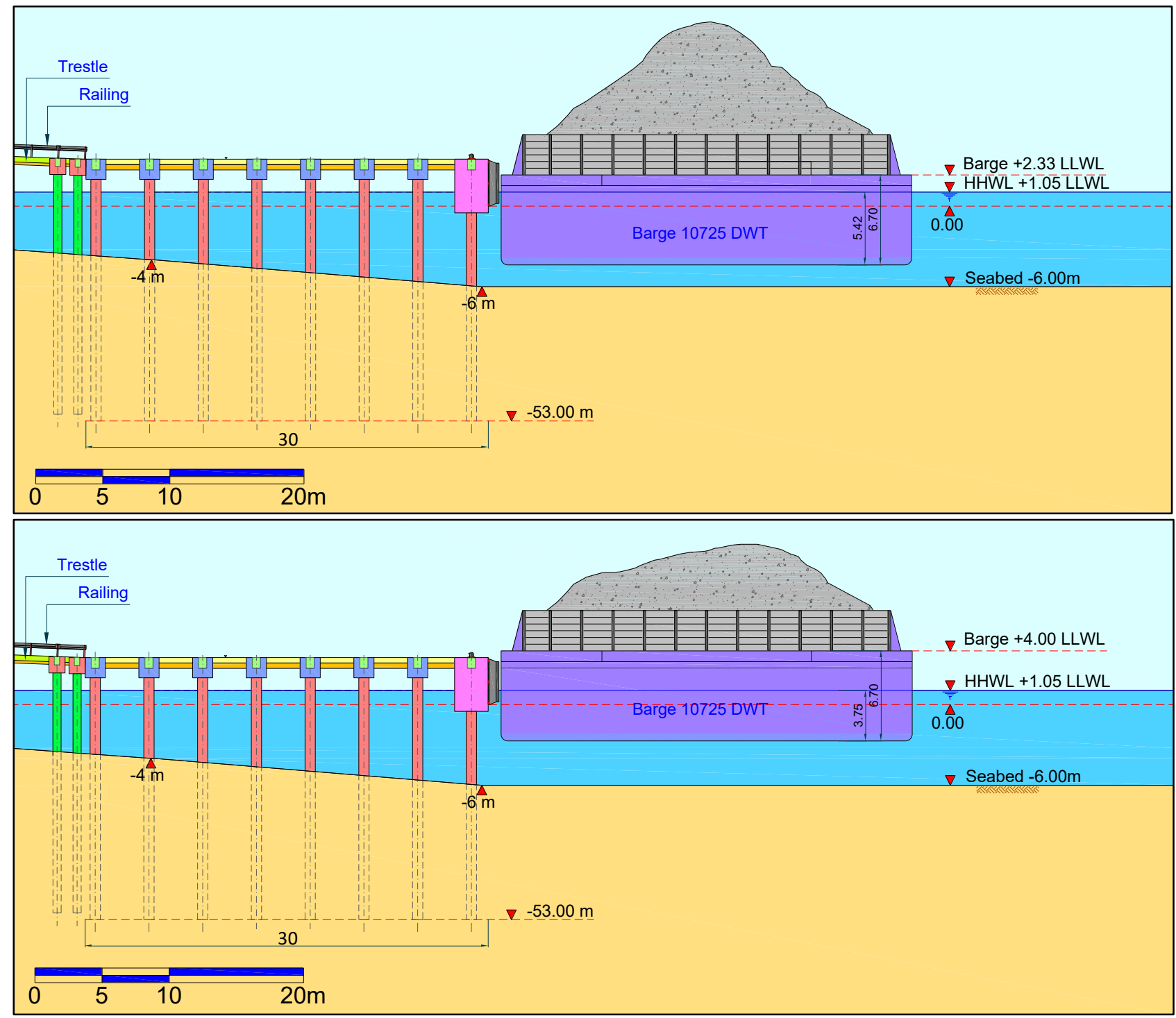

Fig 1 Illustration of barge and jetty level during (a) Phase One and (b) Phase Two. Source: PT LAPI ITB [2]

$$
N O T=\frac{B W T}{7}
$$

Finally, Berth Time (BT) is measured using Equation 5 below.

$$
B T=B W T+N O T
$$

After berth time is measured, measurement of annual cargo throughput is conducted to estimate the value of each system's annual productivity further. The annual throughput of each system follows Equation (6) below.

$$
\text { Throughput }=\frac{Y O T}{B T} \times C \times B O R
$$

While,

YOT = Yearly Operational Time, or the amount of port's operational hours in a year. In this study, these variable equals to 24 hours $\mathrm{x}$ 365 days or 8760 hours.
$C \quad=$ The amount of cargo unloaded from a barge, which equals to 5000 tons.

$B O R=$ Abbreviation for Berth Occupancy Ratio. For this variable, the value of $80 \%$ is chosen based on Sunda Kelapa Port's BOR value (70\%) [4]. This study chooses a higher BOR to represent the operational readiness of one jetty, which should be greater than of one port that consists of more than one jetty.

\subsection{Conventional System (Excavator - Dump Truck}

Berth Time measurement for this system follows the approach given in Fig 4. Analysis based on the system's operational condition regarded as Effective Time is described thoroughly in the subchapters below.

\footnotetext{
$\overline{{ }^{*} \text { Corresponding author: auliauliatiara@gmail.com }}$
} 


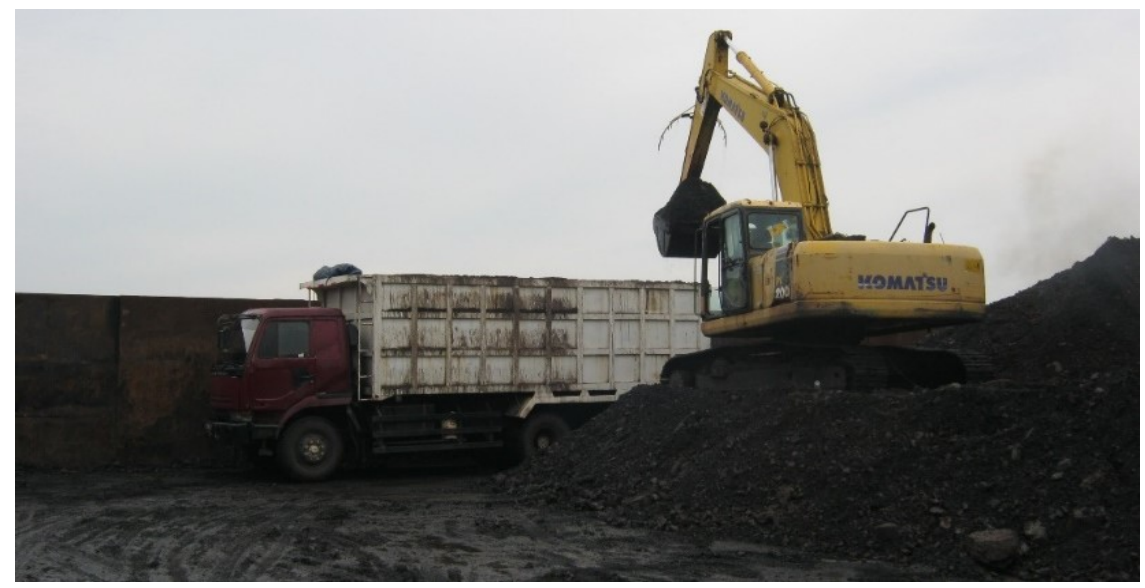

Fig 2 Excavator and Dump Truck coal unloading in Muarajati Wharf, Port of Cirebon. Source: PT LAPI ITB [2]

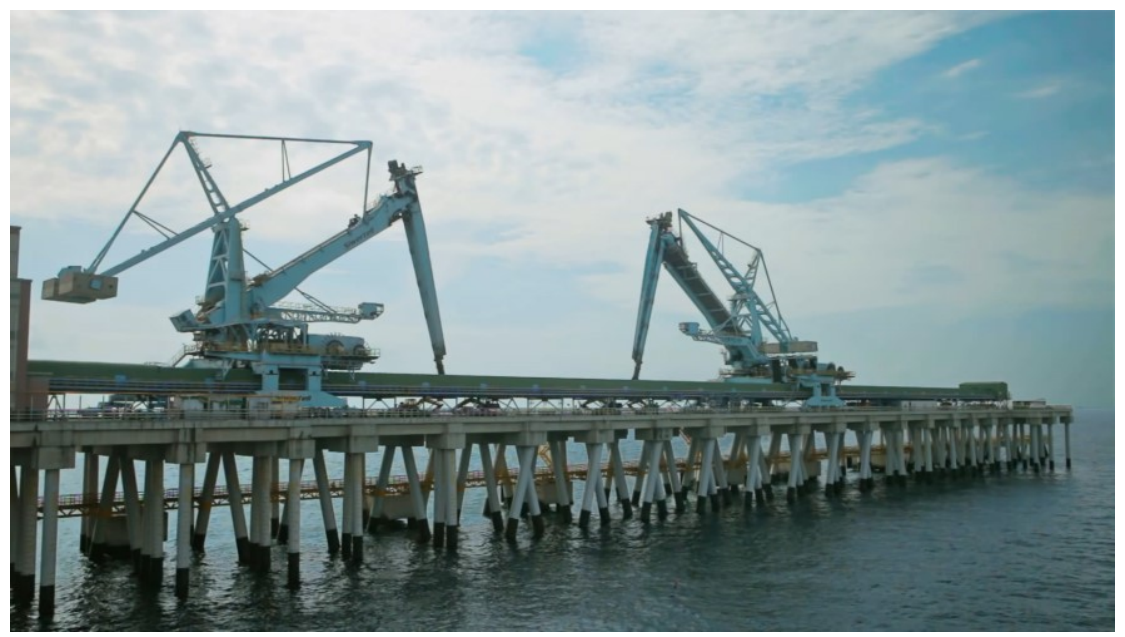

Fig 3 Vertical Screw Conveyor in Talin Power Plant, Taiwan. Source: Company Profile Video Siwertell Ship Unloader

\subsubsection{Phase One}

Phase One of this system consists of the unloading process of bulk cargo from the barge using Excavator into a Dump Truck, and the duration of Dump Truck maneuver to and from the unloading location as shown in Fig 5. The time length of this condition is calculated using the formula Equation (7) below.

$$
\text { Phase One }{ }_{C}=\left(\frac{5000 \text { tons }}{P_{\text {Excavator }}} \times \frac{1}{3} \times O F\right)+\left(M 1_{D T} \times N \times O F\right)
$$

Where,

$\begin{array}{ll}\text { Phase One }_{C}= & \text { The duration of Phase One } \\ & \begin{array}{l}\text { condition for conventional } \\ \text { operational system }\end{array} \\ = & \begin{array}{l}\text { Productivity of Excavator } \\ \text { (ton/hour) }\end{array} \\ P_{\text {Excavator }} & \text { The duration of Dump Truck's } \\ & \text { single maneuver } \\ M 1_{D T} & =\text { The amount of Dump Truck's }\end{array}$

maneuvers, which are: (a) Dump Truck movement from the dumping place to the unloading place, and; (b) Dump Truck movement from unloading place to dumping place

$O F$ $=$ Operational factor of the equipment (taken
as 1.2)

\subsubsection{Intermediate Phase}

Intermediate Phase consists of activities in preparation for Excavator and Dump Truck's movement into the barge. First, the duration of cargo hold unlocking to open a channel for equipment to move inside the barge (presented as $U l_{C H}$ ) is measured. The duration of Ramp Door movement to the channel location by Mobile Crane (presented as $M_{\text {Ramp }}$ ) is calculated, continued by the measurement of the duration of Ramp Door preparation $\left(P_{\text {Ramp }}\right)$ and Ramp Door locking $\left(L_{\text {Ramp }}\right)$. Finally, the duration of Excavator unloading into the barge and equipment's setting $\left(D_{\text {Excavator }}\right)$ is calculated. The whole calculation is briefly summarized in Equation (8) below.

Intermediate Step ${ }_{C}=U l_{C H}+M_{\text {Ramp }}+P_{\text {Ramp }}+$

\footnotetext{
${ }^{*}$ Corresponding author: auliauliatiara@gmail.com
} 


$$
L_{\text {Ramp }}+D_{\text {Excavator }}
$$

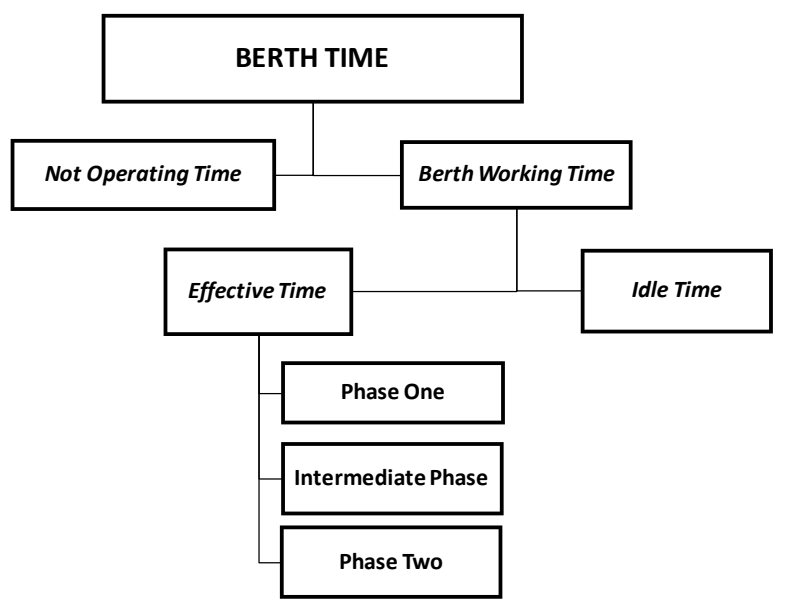

Fig 4 Berth time measurement hierarchy.

Source: Sutanto, et al. [3]

Due to the specification of a conventional Ramp Door, it can only be passed by one vehicle at a time. For that reason, the value $D_{\text {Excavator }}$ is the maneuver duration of 2 Excavators, plus the duration of equipment setting.

$$
D_{\text {Excavator }}=S_{\text {Excavator }}+\left(M_{\text {Excavator }} \text { X OF X N }\right)
$$

Where:

$$
\begin{array}{ll}
D_{\text {Excavator }} & =\begin{array}{l}
\text { Duration of Excavator maneuvering } \\
\text { and setting }
\end{array} \\
S_{\text {Excavator }} & \text { Duration of Excavator setting } \\
M_{\text {Excavator }} & =\begin{array}{l}
\text { Duration of Excavator maneuver into } \\
\text { the barge }
\end{array} \\
N & =\text { Number of Excavators }
\end{array}
$$

\subsubsection{Phase Two}

Truck which located inside the cargo barge as shown in Fig 6. The duration of this condition follows Equation (10).

$$
\text { Phase Two }_{C}=\left(U 2_{\text {Excavator }} \text { OF }\right)+\left(M 1_{D T} \text { X N xOF }\right)
$$

Where:

$$
\begin{array}{ll}
\text { Phase } T w o_{C}= & \text { The duration of Phase Two } \\
& \begin{array}{l}
\text { condition for conventional } \\
\text { operational system }
\end{array} \\
= & \text { The unloading duration of } 2 / 3 \text { part } \\
& \text { of bulk cargo by Excavator inside } \\
& \text { the cargo barge } \\
= & \text { The duration of Dump Truck's } \\
& \text { single maneuver into the cargo } \\
& \text { barge. } \\
= & \text { The amount of Dump Truck's } \\
& \text { maneuvers, which are: (a) Dump }
\end{array}
$$

\footnotetext{
* Corresponding author: auliauliatiara@gmail.com
}

Truck movement from the dumping place to the unloading place inside the barge, and; (b) Dump Truck movement from unloading place inside the barge to dumping area.

$O F$

$$
\begin{aligned}
& =\text { Operational factor of the } \\
& \text { equipment, regarded with a value } \\
& \text { of } 1.2 \text {. }
\end{aligned}
$$

A conventional Ramp Door can only be passed by one vehicle at a time. Thus, the process of unloading by 2 Excavators will not be in exact parallel. Instead, two unloading processes will work in parallel with the interval duration of Dump Truck maneuver $\left(M 1_{\text {Dump Truck }}\right)$ to the inside of the barge. Then, the duration of Phase Two's unloading process ( $\left.U 2_{\text {Excavator }}\right)$ will be a summation of the first Dump Truck's maneuver into the barge, Excavator's unloading process ( $U 1_{\text {Excavator }}$ ), the maneuver of the second Dump Truck into the barge, and the maneuver of the first Dump Truck out of the barge. This process is described in Equation (11) below.

$$
U 2_{\text {Excavator }}=\left(\frac{5000 \text { tons }}{P_{\text {Excavator }}} \times \frac{2}{3}\right)+\left(3 \times M 1_{D T}\right)
$$

After the variables in the subchapters are measured, ET can be concluded by following Equation (1). Then, following Equation (2), Equation (3), Equation (4) to Equation (5) respectively, IT, BWT, NOT and finally, $B T$ can be measured. Then, annual throughput measurement can be done using Equation (6).

\subsection{Modern System (Vertical Screw Conveyor - Conveyor Belt)}

Similar to the Conventional System, the Berth Time measurement for Modern Operational System also follows the approach given in Fig 4. Analysis based on the system's operational condition regarded as Effective Time is described thoroughly in the subchapters below.

\subsubsection{Phase One}

Phase One of this system consists of the unloading process of bulk cargo from the barge using Vertical Screw Conveyor as shown in Fig 7. The duration is calculated using the formula Equation (12) below.

$$
\begin{aligned}
& S 1_{M}=\left(U 1_{V S C} x O F\right) \\
& U 1_{V S C}=\left(\frac{5000 \text { tons }}{P_{V S C}} \times \frac{1}{3}\right)
\end{aligned}
$$

Where:

$$
\begin{aligned}
S 1_{M} & =\text { The duration of Phase One condition } \\
& \text { for Modern Operational System } \\
& =\text { The unloading duration of } 1 / 3 \text { part of } \\
& \text { bulk cargo by Vertical Screw } \\
& \text { Conveyor }
\end{aligned}
$$




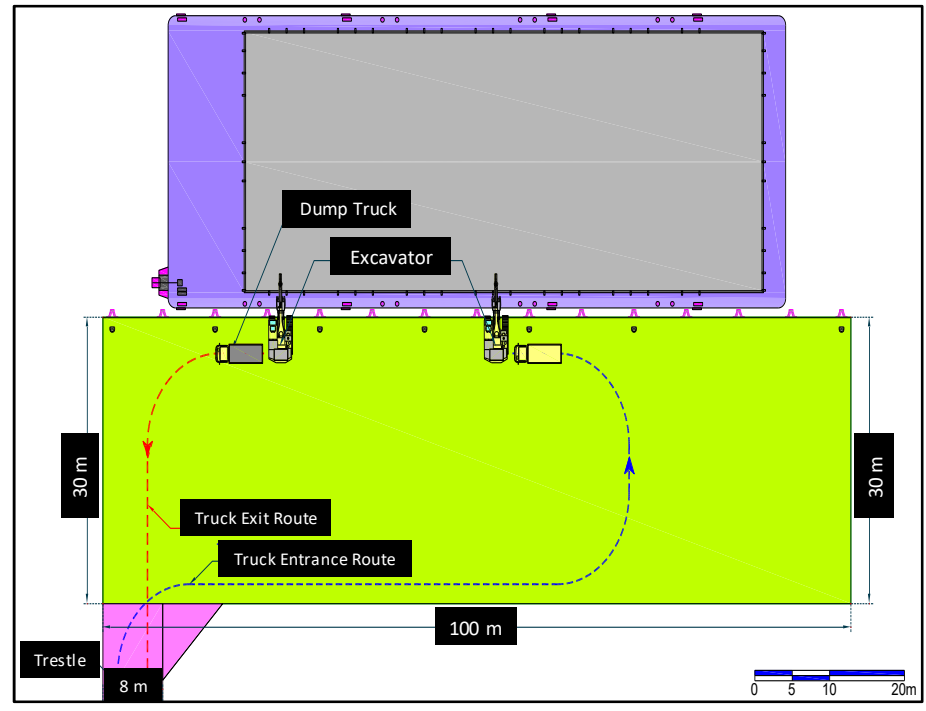

Fig 5 Conventional Operational System during Phase One.

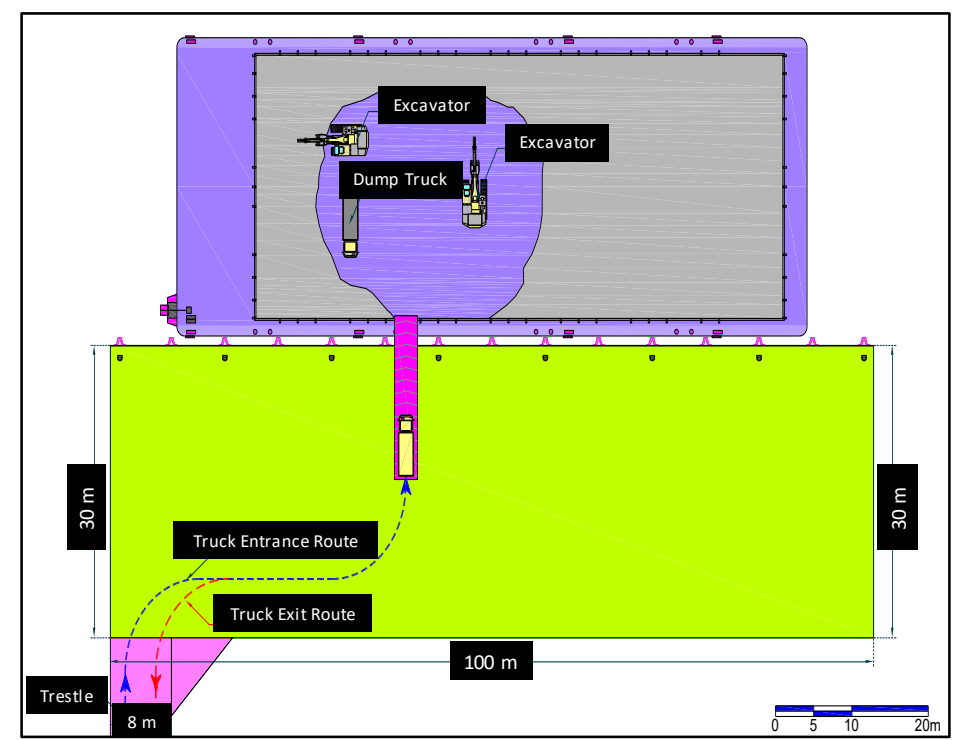

Fig 6 Conventional Operational System during Phase Two. $\begin{aligned} P_{V S C}= & \text { Productivity of Vertical Screw } \\ & \text { Conveyor (ton/hour) }\end{aligned}$

\subsubsection{Intermediate Phase}

Intermediate Phase for this system consists of activities in preparation for Bulldozer movement into the barge to conduct Phase Two as shown in Fig 8. The events that occur in this condition follows Equation (14) below:

$$
\begin{gathered}
\text { Int } \text { Phase }_{M}=U l_{C H}+M_{\text {Ramp }}+P_{\text {Ramp }}+L_{\text {Ramp }}+ \\
M_{\text {Bulldozer }}
\end{gathered}
$$

Where:

$$
\begin{aligned}
M_{\text {Bulldozer }}= & \text { The duration of Bulldozer's } \\
& \text { maneuver into the cargo barge }
\end{aligned}
$$

\subsubsection{Phase Two}

Phase One condition of this system consists of the unloading process of bulk cargo from the barge using Vertical Screw Conveyor. The duration of this condition is calculated using Equation (15) below.

$$
\begin{gathered}
\text { Step Two } \\
\mathrm{WL}_{M}=\left(U 2_{V S C} x \text { OF }\right) \\
U 2_{V S C}=\left(\frac{5000 \text { tons }}{P_{V S C}} \times \frac{2}{3}\right)
\end{gathered}
$$

Where:

Phase $\mathrm{Two}_{M} \quad=$ The duration of Phase Two condition for Modern Operational System

$U 2_{V S C} \quad=$ The unloading duration of $2 / 3$ part of bulk cargo by Vertical Screw Conveyor

\footnotetext{
* Corresponding author: auliauliatiara@gmail.com
} 


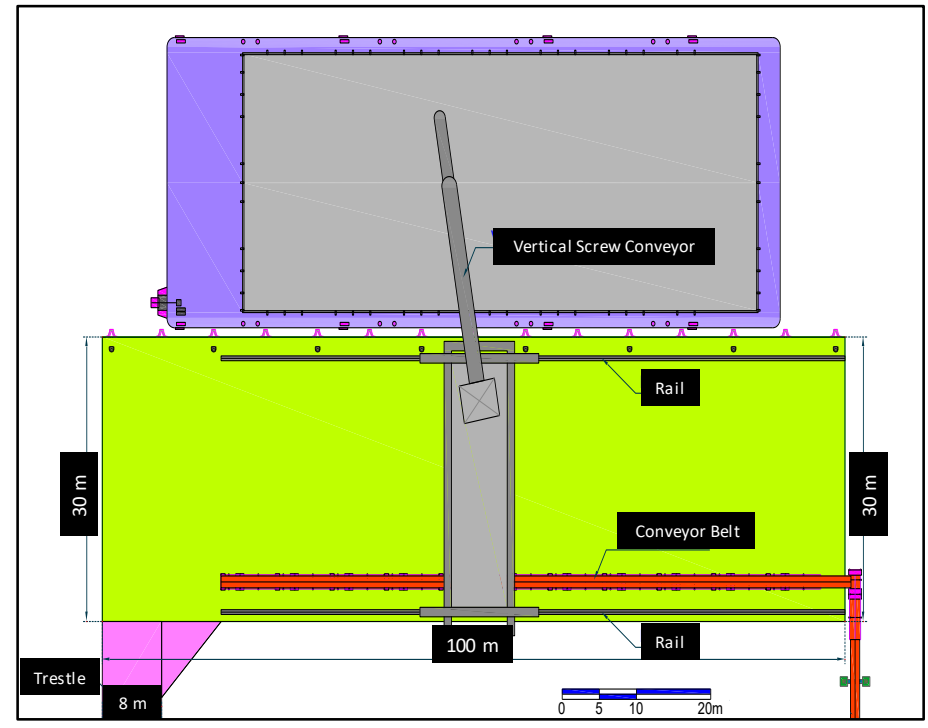

Fig 7 Modern Operational System during Phase One.

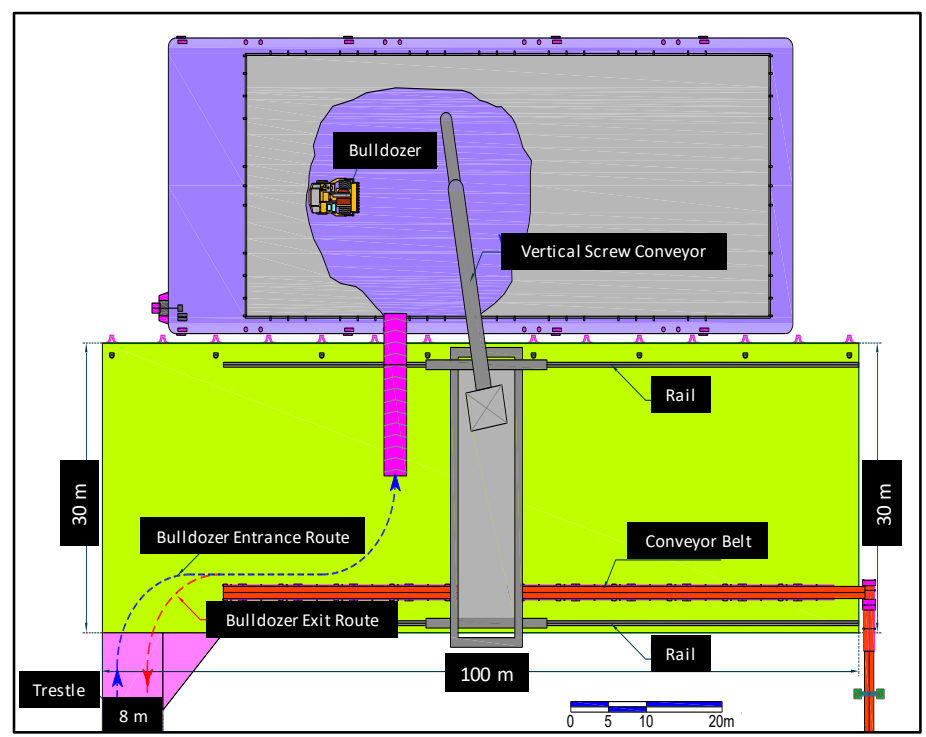

Fig 8 Modern Operational System during Phase Two.

$$
\begin{aligned}
P_{V S C}= & \text { Productivity of Vertical Screw } \\
& \text { Conveyor (ton/hour) }
\end{aligned}
$$

After the variables in the subchapters are measured, ET can be concluded by following Equation (1). Then, by following Equation (2), Equation (3), Equation (4) to Equation (5) respectively, IT, BWT, NOT and finally BT can be measured. Then, annual throughput measurement can be done using Equation (6).

\subsection{Summary and Discussion}

The summary of productivity measurement is shown in Table 1 for the Conventional System and Table 2 for the Modern System. The comparison between the systems is shown in Fig 9. The result shows that regarding unloading productivity, the Modern System is almost three times faster than the Conventional System. The most time-consuming phase of both system is Phase Two, due to the large amount of cargo unloaded. Despite the Conventional System's long berthing time (26 hours for 5,000-ton dry bulk unloading), two days of berthing time is still considered as acceptable based on the observation in Port of Cirebon conducted by PT LAPI ITB [2].

\section{Financial Simulation and Analysis}

Financial simulation and analysis of each operating system is crucial to measure the feasibility of the investment for port operators, and as an approach to choose the best operating system with higher profits and less capital cost. In simulating the cash flow of the operating system and infrastructure, this study follows a set of scenario, income, and expenditure components. After the financial simulation is conducted, financial analysis is done using three kinds of feasibility measurement, which are BCR, IRR, and PP. These

\footnotetext{
*Corresponding author: auliauliatiara@gmail.com
} 
financial assessment variables will show the best operational scheme for investment.

Table 1 Productivity Measurement of Conventional Operational System

\begin{tabular}{|c|c|c|}
\hline Variables & Value & Source \\
\hline$P_{\text {Excavator }}$ & 357 ton/hour & $\begin{array}{l}\text { Survey on Cargo } \\
\text { Unloading } \\
\text { Mechanism in IPC } \\
\text { Cirebon, December } \\
2016 \text { [1] }\end{array}$ \\
\hline$O F$ & 1.2 & Assumption \\
\hline$M 1_{D T}$ & 1 minute & Assumption \\
\hline$N$ & 2 units & $\begin{array}{l}\text { Survey on Cargo } \\
\text { Unloading } \\
\text { Mechanism in IPC } \\
\text { Cirebon, December } \\
2016 \text { [1] }\end{array}$ \\
\hline Phase One ${ }_{C}$ & 4.7 hours & \\
\hline$U l_{C H}$ & 20 minutes & $\begin{array}{l}\text { Sasono, Herman Budi } \\
\text { (2012) [5] }\end{array}$ \\
\hline$M_{\text {Ramp }}$ & 1 minute & Assumption \\
\hline $\boldsymbol{P}_{\text {Ramp }}$ & 5 minutes & Assumption \\
\hline$L_{\text {Ramp }}$ & 5 minutes & Assumption \\
\hline$S_{\text {Excavator }}$ & 10 minutes & Assumption \\
\hline$M_{\text {Excavator }}$ & 1 minute & Assumption \\
\hline$N$ & 2 & $\begin{array}{l}\text { Survey on Cargo } \\
\text { Unloading } \\
\text { Mechanism in IPC } \\
\text { Cirebon, December } \\
2016 \text { [1] }\end{array}$ \\
\hline Intermediate P & 0.72 hour & \\
\hline Phase Two ${ }_{C}$ & 16.7 hours & \\
\hline
\end{tabular}

\subsection{Financial Simulation Scenarios}

List of scenarios used in this financial simulation are listed below:

a. The construction year of Post VI Jetty and its operating system is assumed to be 2017.

b. The first operational year of Post VI Jetty is assumed to be 2018 with the project concession period of 50 years.

c. The cargo throughput of the first operational year follows Equation 17 below.

Throughput $_{1 s t}=$ Throughput $_{2015} x(1+i)^{n}$

In which,

Throughput $_{1 s t}=$ Cargo throughput of Post VI jetty's first operational year.

Throughput $_{2015}=$ Sand bulk cargo throughput of Sunda Kelapa Port in 2015 for one jetty

$i \quad=$ Throughput growth percentage per year (assumed to have a value of $10 \%$ )

$n \quad=$ The year of the first operational throughput - the year of the data

$=2018-2015$

* Corresponding author: auliauliatiara@gmail.com
Table 2 Productivity Measurement of Modern Operational System

\begin{tabular}{|c|c|c|}
\hline Variables & Value & Source \\
\hline$P_{V S C}$ & 1000 ton/hour & $\begin{array}{l}\text { Siwertell } \\
\text { Ship } \\
\text { Unloader's } \\
\text { productivity } \\
{[6]}\end{array}$ \\
\hline$O F$ & 1.2 & Assumption \\
\hline$U 1_{V S C}$ & 1.67 hours & \\
\hline Phase one $_{M}$ & 2 hours & \\
\hline$U l_{C H}$ & 20 minutes & $\begin{array}{l}\text { Sasono } \\
(2012)[5]\end{array}$ \\
\hline$M_{\text {Ramp }}$ & 1 minute & Assumption \\
\hline$P_{\text {Ramp }}$ & 5 minutes & Assumption \\
\hline$L_{\text {Ramp }}$ & 5 minutes & Assumption \\
\hline$S_{\text {Excavator }}$ & 10 minutes & Assumption \\
\hline$M_{\text {Bulldozer }}$ & 1.2 minute & Assumption \\
\hline Intermediate Phase ${ }_{M}$ & 0.5 hour & \\
\hline Phase Two $_{M}$ & 4 hours & \\
\hline
\end{tabular}

d. After the first operational year, the throughput percentages of the following years grow each year with the value of $10 \%$, as stated in Equation (17) until finally being constant in throughput percentage of $100 \%$.

e. $30 \%$ part of the capital investment is funded with bank loan with the installment plan of 50 years and $10 \%$ bank interest.

f. $70 \%$ part of the capital investment is funded with equity.

g. Increase in port service rates is assumed to occur every three years with the amount of $10 \%$.

h. Discount Rate or the rate value for accounting the future value factor in the project's cash flow is assumed to be $10 \%$.

i. The amount of cargo stored in the port's terminal is assumed to be $70 \%$ of its annual throughput.

\subsection{Income Components}

Income components included in this study refers to port service rates for port users. Details on income components are described in Table 3.

\subsection{Expenditure Components}

The components of expenditure in this financial analysis consist of Post VI Jetty construction cost, the capital cost of each operational systems, operational tariffs, insurance, and taxation, which is presented in detail in Table 4. 


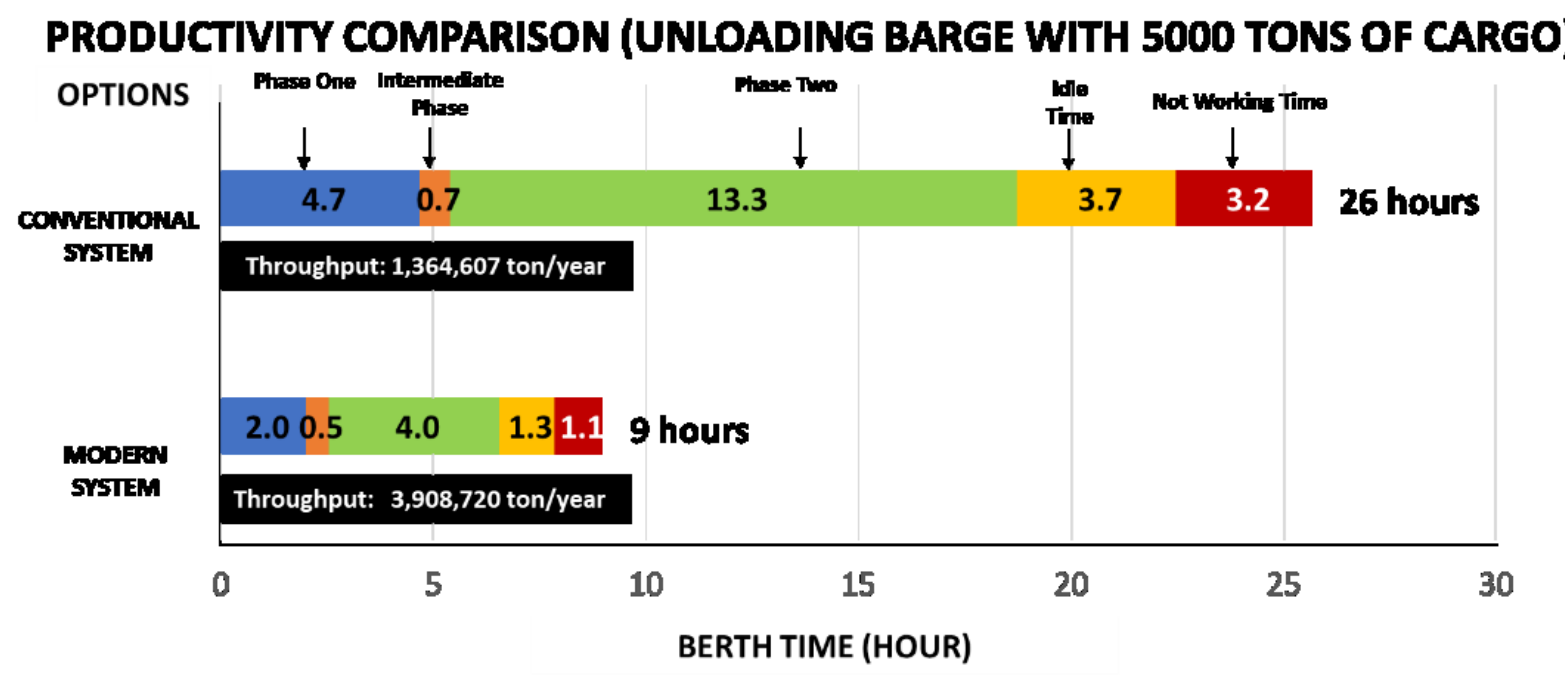

Fig 9 Productivity Comparison between Conventional and Modern Operational System.

\subsection{Financial Feasibility Components}

\subsubsection{Benefit/Cost Ratio (BCR)}

This component is a ratio between income components, presented as the value of benefit, and expense components as the value of cost in the cash flow. This ratio follows the formula below:

$$
B / C=\frac{\text { Present Value Benefits }}{\text { Present Value Cost }}
$$

The decision guideline for this feasibility measurement component, as stated by Blank and Tarquin [10] is given below:

If $B / C \geq 1.0$, accept the project as economically acceptable for the estimates and discount rate applied.

If $B / C<1.0$, the project is not economically acceptable.

\subsubsection{Internal Rate of Return (IRR)}

Internal rate of return is a discount rate that makes the net present value (NPV) of the project's cash flow equals zero. IRR follows the formula below:

$$
N P V=\sum_{t=1}^{T} \frac{C_{t}}{(1+r)^{t}}-C_{o}=0
$$

Where:

$C_{t}=$ Net cash inflow during the period $\mathrm{t}$

$C_{O}=$ Total initial investment cost

$r \quad=$ The value of IRR

$t \quad=$ The year value of the cash flow

\begin{tabular}{|c|c|c|c|}
\hline No. & $\begin{array}{c}\text { Income } \\
\text { Components }\end{array}$ & Value & Source \\
\hline 1 & $\begin{array}{l}\text { Vessel } \\
\text { Anchoring } \\
\text { Tariff }\end{array}$ & $\begin{array}{l}\text { IDR } 100 \text { per } \\
\text { GT (Gross } \\
\text { Tonnage) }\end{array}$ & $\begin{array}{l}\text { Port of } \\
\text { Indonesia's } \\
\text { decree [7] }\end{array}$ \\
\hline 2 & $\begin{array}{l}\text { Vessel } \\
\text { Mooring Tariff }\end{array}$ & $\begin{array}{l}\text { IDR } 100 \text { per } \\
\text { GT (Ramp } \\
\text { Door setting } \\
\text { included) }\end{array}$ & $\begin{array}{l}\text { Port of } \\
\text { Indonesia's } \\
\text { decree [7] }\end{array}$ \\
\hline 3 & $\begin{array}{l}\text { Jetty Facility } \\
\text { Tariff }\end{array}$ & $\begin{array}{l}\text { IDR } 2,250 \text { per } \\
\text { cargo tonnage }\end{array}$ & $\begin{array}{l}\text { Feasibility } \\
\text { Study of Port of } \\
\text { Sunda Kelapa } \\
{[8]}\end{array}$ \\
\hline 4 & $\begin{array}{l}\text { Stevedoring } \\
\text { Tariff }\end{array}$ & $\begin{array}{l}\text { IDR } 22,000 \text { per } \\
\mathrm{m}^{3} \text { of cargo }\end{array}$ & $\begin{array}{l}\text { Port of } \\
\text { Indonesia's } \\
\text { decree [7] }\end{array}$ \\
\hline 5 & $\begin{array}{l}\text { Bulk Terminal } \\
\text { Tariff }\end{array}$ & $\begin{array}{l}\text { IDR } 250 \text { per } \\
\text { cargo tonnage }\end{array}$ & $\begin{array}{l}\text { Port of } \\
\text { Indonesia's } \\
\text { decree [7] }\end{array}$ \\
\hline \multirow[t]{4}{*}{6} & $\begin{array}{l}\text { Water Supply } \\
\text { Tariff }\end{array}$ & & \multirow{4}{*}{$\begin{array}{l}\text { Feasibility } \\
\text { Study of Port of } \\
\text { Sunda Kelapa } \\
{[8]}\end{array}$} \\
\hline & $\begin{array}{l}\text { Bulk Water } \\
\text { Tariff }\end{array}$ & $\begin{array}{l}\text { IDR } 40,000 \text { per } \\
\text { ton }\end{array}$ & \\
\hline & $\begin{array}{l}\text { PH Meter } \\
\text { Maintenance }\end{array}$ & $\begin{array}{l}\text { IDR 20,000 per } \\
\text { unit vessel }\end{array}$ & \\
\hline & $\begin{array}{l}\text { Other } \\
\text { Maintenance }\end{array}$ & $\begin{array}{l}\text { IDR } 7500 \text { per } \\
\text { unit vessel }\end{array}$ & \\
\hline 7 & $\begin{array}{l}\text { Cargo Pass } \\
\text { Tariff }\end{array}$ & $\begin{array}{l}\text { IDR } 8,182 \text { per } \\
25 \text { tons of } \\
\text { cargo }\end{array}$ & $\begin{array}{l}\text { Feasibility } \\
\text { Study of Port of } \\
\text { Sunda Kelapa } \\
{[8]}\end{array}$ \\
\hline
\end{tabular}

Table 3 Income Components

The project can be decided as economically acceptable if the value of IRR $(r)$ follows this condition:

$$
r>\text { Discount Rate }
$$

\footnotetext{
* Corresponding author: auliauliatiara@gmail.com
} 


\subsubsection{Payback Period (PP)}

Payback period (PP) method is used to quantify the length of time required to recover the cost of an investment. The payback period of an investment is an important determinant of whether to commence the project, as longer payback periods are not desirable for investment positions. Thus, for two comparable investment options with the same rate of return value and risk, this feasibility measurement is used to select an option with the quickest investment recovery.

Table 4 Expenditure Components

\begin{tabular}{|c|c|c|c|}
\hline No. & $\begin{array}{l}\text { Expenditure } \\
\text { Components } \\
\end{array}$ & Value & Source \\
\hline 1 & $\begin{array}{l}\text { Post VI Jetty } \\
\text { Construction } \\
\text { Cost }\end{array}$ & $\begin{array}{l}\text { IDR } \\
72,128,902,102\end{array}$ & $\begin{array}{l}\text { Post VI Jetty } \\
\text { Engineering } \\
\text { Report [1] }\end{array}$ \\
\hline 2 & $\begin{array}{l}\text { Operational } \\
\text { System } \\
\text { Capital Cost }\end{array}$ & $\begin{array}{l}\text { Depends on each } \\
\text { system }\end{array}$ & $\begin{array}{l}\text { Port of } \\
\text { Indonesia's } \\
\text { decree [7] }\end{array}$ \\
\hline 3 & $\begin{array}{l}\text { Bulk Terminal } \\
\text { Operational } \\
\text { Cost }\end{array}$ & $\begin{array}{l}70 \% \text { of Bulk } \\
\text { Terminal } \\
\text { income }\end{array}$ & $\begin{array}{l}\text { Feasibility } \\
\text { Study of Port } \\
\text { of Sunda } \\
\text { Kelapa [8] }\end{array}$ \\
\hline 4 & $\begin{array}{l}\text { Water Supply } \\
\text { Operational } \\
\text { Cost }\end{array}$ & $\begin{array}{l}30 \% \text { of Water } \\
\text { Supply income }\end{array}$ & $\begin{array}{l}\text { Port of } \\
\text { Indonesia's } \\
\text { decree [7] }\end{array}$ \\
\hline 5 & $\begin{array}{l}\text { Cargo Pass } \\
\text { Operational } \\
\text { Cost } \\
\end{array}$ & $\begin{array}{l}30 \% \text { of Cargo } \\
\text { Pass income }\end{array}$ & $\begin{array}{l}\text { Port of } \\
\text { Indonesia's } \\
\text { decree [7] }\end{array}$ \\
\hline 6 & $\begin{array}{l}\text { Vessel } \\
\text { Handling Cost }\end{array}$ & $\begin{array}{l}30 \% \text { of Vessel } \\
\text { Handling } \\
\text { income }\end{array}$ & \\
\hline 7 & $\begin{array}{l}\text { Conveyor Belt } \\
\text { Maintenance } \\
\text { Cost } \\
\end{array}$ & $\begin{array}{l}25 \% \text { of } \\
\text { Conveyor Belt's } \\
\text { capital cost }\end{array}$ & Assumption \\
\hline 8 & $\begin{array}{l}\text { Indirect } \\
\text { Operational } \\
\text { Cost } \\
\end{array}$ & $\begin{array}{l}0.1 \% \text { of the total } \\
\text { income }\end{array}$ & Assumption \\
\hline 9 & $\begin{array}{l}\text { Other } \\
\text { Operational } \\
\text { Cost } \\
\end{array}$ & $\begin{array}{l}0.08 \% \text { of the } \\
\text { total income }\end{array}$ & Assumption \\
\hline 10 & $\begin{array}{l}\text { Insurance } \\
\text { Cost }\end{array}$ & $\begin{array}{l}0.05 \% \text { of the } \\
\text { construction cost }\end{array}$ & Assumption \\
\hline 11 & Tax & $\begin{array}{l}10 \% \text { of the total } \\
\text { income }\end{array}$ & $\begin{array}{l}\text { Assumption } \\
\text { based on Bank } \\
\text { of Indonesia } \\
\text { (BI) Rate in } 10 \\
\text { years [9] }\end{array}$ \\
\hline
\end{tabular}

\subsection{Financial Simulation Result}

After conducting the simulation of two investment options by calculating all income and expenditure components detailed in subchapter 4.1 to 4.4 , the financial feasibility assessment based on subchapter 4.5 is measured. The result of the process is shown on Table 5.

\subsection{Discussion}

Table 5 shows that the Conventional System has a resembling quantity of financial performance to its opposite. With the capital cost of almost the half the
Modern System, Conventional System will result to 13year payback period, only a year later than the Modern System. That way, by choosing the Conventional System, port operator will save $50 \%$ of capital cost to have only one added year of investment recovery.

Table 5 Financial Simulation Result

\begin{tabular}{|c|c|c|c|c|}
\hline Options & BCR & IRR & PP & $\begin{array}{c}\text { Capital Cost } \\
\text { (IDR) }\end{array}$ \\
\hline $\begin{array}{c}\text { Conventional } \\
\text { System }\end{array}$ & 1.69 & $14.60 \%$ & $\begin{array}{c}13 \\
\text { years }\end{array}$ & $75,178,382,000$ \\
\hline $\begin{array}{c}\text { Modern } \\
\text { System }\end{array}$ & 2.12 & $15.78 \%$ & $\begin{array}{c}12 \\
\text { years }\end{array}$ & $145,178,634,000$ \\
\hline
\end{tabular}

\section{Conclusion}

This simulation concludes that with the exact circumstances, these operational systems, with two times difference in capital cost, result in similar financial feasibility values. That way, conventional operating system will be the most economically-suitable option for Post VI Jetty of Sunda Kelapa Port. This phenomenon happens because, in a small infrastructure where the operational capability is limited, a modern operating system will not work on its maximum capability. With a limited amount of operational and financial productiveness, the cash flow of the project will take just the similar amount of time to the conventional operating system to recover the capital investment. Hence, the use of a traditional operating system will bring more advantages to the project.

\section{References}

1. Prihatono, Bambang, Pengembangan Tol Laut Dalam RPJMN 2015-2019 dan Implementasi 2015, State Ministry of National Development Planning (BAPPENAS) (2015)

2. PT LAPI ITB, Laporan Akhir Perencanaan Pembangunan Dermaga/Jetty Curah Kering di Apron Pos VI Muara Baru Cabang Pelabuhan Sunda Kelapa, PT Pelabuhan Indonesia II Cabang Sunda Kelapa (2016)

3. Sutanto, Harry et al., Referensi Kepelabuhanan Seri 06 Edisi II: Pengoperasian Pelabuhan, PT Pelabuhan Indonesia (Persero), p 27-50 (2010)

4. Directorate General of Sea Transportation, Peraturan Direktur Jenderal Perhubungan Laut Nomor: HK.103/2/18/DJPL-16 tentang Standar Kinerja Pelayanan Operasional Pelabuhan pada Pelabuhan yang Diusahakan Secara Komersial, Ministry of Transportation (2016)

5. Sasono, Herman Budi, Manajemen Pelabuhan dan Realisasi Ekspor Impor, Andi Offset, p 135 (2012)

\footnotetext{
* Corresponding author: auliauliatiara@gmail.com
} 
6. Siwertell, High Capacity Ship Unloader, Cargotec Sweden AB Bulk Handling, https://cargotec.picturepark.com/Website/?Action $=$ downloadAsset\&AssetId=33001 (2016, December 16)

7. Board of Directors of PT Pelabuhan Indonesia II Cabang Sunda Kelapa, Surat Keputusan Direksi PT Pelabuhan Indonesia II (Persero) tentang Tarif Jasa Kapal dan Barang Pelabuhan Sunda Kelapa, PT Pelabuhan Indonesia II Cabang Sunda Kelapa, (2012)

8. PT LAPI ITB, Feasibility Study Penyiapan Lahan Untuk Penataan Pelabuhan Sunda Kelapa, PT Pelabuhan Indonesia II Cabang Sunda Kelapa (2014)

9. Bank of Indonesia, Data BI Rate, Bank of Indonesia, http://www.bi.go.id/en/moneter/birate/data/Default.aspx (2017, February 2)

10. Blank, Leland \& Tarquin, Anthony, Basics of Engineering Economy, McGraw-Hill, p 166 168. (2008)

* Corresponding author: auliauliatiara@gmail.com 